\title{
Article \\ Chemical Bath Deposited Orthorhombic SnS Films for Solar Cell Applications
}

\author{
Carlos Ocampo-Ortega ${ }^{1}$, Ines Riech ${ }^{1, * \mathbb{C}}$, Arturo Abelenda ${ }^{1}$, Ricardo Mis-Fernández ${ }^{2}$, \\ Patricia Rodríguez-Fragoso ${ }^{3}$ and Julio Mendoza-Alvarez ${ }^{3}$
}

1 Materials Science Laboratory, Faculty of Engineering, Autonomous University of Yucatan, Merida 97130, Mexico; ocampo.ortega.carlos@hotmail.com (C.O.-O.); aabelenda@gmail.com (A.A.)

2 Applied Physics Department, Cinvestav-IPN, Merida 97310, Mexico; rimis@cinvestav.com

3 Physics Department, Cinvestav-IPN, Mexico City 07360, Mexico; prodriguez@fis.cinvestav.mx (P.R.-F.); julio.mendoza@cinvestav.mx (J.M.-A.)

* Correspondence: ines.riech@correo.uady.mx

check for

updates

Citation: Ocampo-Ortega, C.; Riech,

I.; Abelenda, A.; Mis-Fernández, R.; Rodríguez-Fragoso, P.; Mendoza-

Alvarez, J. Chemical Bath Deposited Orthorhombic SnS Films for Solar

Cell Applications. Coatings 2022, 12, 283. https://doi.org/10.3390/

coatings 12020283

Academic Editors: Leiping Duan and Ashraf Uddin

Received: 25 January 2022

Accepted: 15 February 2022

Published: 21 February 2022

Publisher's Note: MDPI stays neutral with regard to jurisdictional claims in published maps and institutional affiliations.

Copyright: (C) 2022 by the authors. Licensee MDPI, Basel, Switzerland. This article is an open access article distributed under the terms and conditions of the Creative Commons Attribution (CC BY) license (https:// creativecommons.org/licenses/by/ $4.0 /)$.

\begin{abstract}
Tin sulfide (SnS) thin films were deposited by the chemical bath deposition technique. The used procedure allows us to obtain orthorhombic SnS in $3.5 \mathrm{~h}$ and achieve thicknesses of $390 \mathrm{~nm}$. We study the influence of deposition times, percentage of Sn precursor, and post-annealing on the structural and optical properties. The X-ray diffraction measurements of SnS films prepared at a deposition time of $3 \mathrm{~h}$ showed orthorhombic structure with characteristic peaks of $\mathrm{SnS}_{2}$. However, increasing the deposition time and the Sn precursor, the orthorhombic SnS phase in these samples becomes predominant. Thin-film morphologies and thicknesses were identified by scanning electron microscopy (SEM). An increase in bandgap from $1.41 \mathrm{eV}$ to $1.56 \mathrm{eV}$ was observed by increasing $\mathrm{Sn}$ precursor. The optical properties remain constant after air annealing of $285^{\circ} \mathrm{C}$. Low-temperature photoluminescence spectra show emission bands at $2.5 \mathrm{eV}$ attributed to the presence of $\mathrm{SO}_{2}$. Other deep level transitions were observed at about $0.9 \mathrm{eV}$, probably due to oxygen.
\end{abstract}

Keywords: SnS thin film; chemical bath deposition; crystal structure; optical properties

\section{Introduction}

Tin sulfide (SnS) is considered a promising absorber layer for Cd-free thin-film solar cells due to its excellent optoelectronic properties. Moreover, $\mathrm{SnS}$ is a binary compound semiconductor composed of non-toxic and earth-abundant materials. Its bandgap $(1.3-1.4 \mathrm{eV})$ is near to the optimum range of $1.3-1.5 \mathrm{eV}$, and its absorption coefficient is appreciably high in the visible region $\left(>10^{4} \mathrm{~cm}^{-1}\right)[1,2]$. Although its theoretical energy conversion efficiency $(\eta)$ is nearly $32 \%$, at par with crystalline silicon solar cells [3], at present, the conversion efficiency record of SnS based solar cells is only 4.63\% [4]. Therefore, a better understanding of the structural, chemical, and physical characteristics of SnS is required to achieve higher efficiencies.

The SnS compound usually possesses an orthorhombic crystal structure at room temperature and pressure with $\mathrm{a}=0.432, \mathrm{~b}=1.12$, and $\mathrm{c}=0.398 \mathrm{~nm}$ (JCPDS card No: 39-0354) lattice parameters. The different elemental compositions of tin and sulfur can form several binary compounds such as $\mathrm{SnS}, \mathrm{SnS}_{2}, \mathrm{Sn}_{2} \mathrm{~S}_{3}$, and other phases [5]. The simultaneous presence of these phases in tin sulfide films can affect their electrical and optical characteristics. For example, when a p-type phase ( $\mathrm{SnS})$ and an n-type phase $\left(\mathrm{SnS}_{2}, \mathrm{Sn}_{2} \mathrm{~S}_{3}\right.$,or both simultaneously) co-exist could result in an inversion of the conductivity type [6].

SnS thin films have been fabricated by different methods such as thermal evaporation [7], radio frequency (RF) sputtering [8], electron beam evaporation [9], chemical vapor deposition [10], successive ionic layer deposition [11], atomic layer deposition (ALD) [4], electrochemical deposition [12,13], and chemical spray pyrolysis [14,15]. To date, the best reported efficiency has been by the slow and expensive atomic layer deposition (ALD) 
process. Chemical bath deposition (CBD) has been reported to be a promising alternative method [16-22] because of its simplicity, low cost, and the possibility of obtaining large-area films. In CBD, the formation of the film takes place when the ionic product exceeds the solubility product. However, optimization of growth conditions, such as deposition time and solution concentration, is essential to avoid unnecessary precipitation, loss of materials during the deposition process, and the appearance of unwanted secondary phases of tin sulfide [23].

This work uses a method first reported in 2021 [24] that allows us to grow orthorhombic $\mathrm{SnS}$ thin films of $390 \mathrm{~nm}$ in $3.5 \mathrm{~h}$. There are reported methods to obtain orthorhombic $\mathrm{SnS}$ by CBD with deposition times of $8,17,24,30$, and up to $40 \mathrm{~h}[20,21,25-27]$ and just a few with times below $6 \mathrm{~h}$ [28-30]. We study the effect of deposition time and percentage of $\mathrm{Sn}$ precursor on structural and optical properties of SnS thin films. Our main goal is to study the conditions in the growth process by CBD of tin monosulfide ( $\mathrm{SnS}$ ) thin film to obtain the best quality of the film and avoid post-growth treatments.

This work is based on a method first reported in 2021 [24], which focuses on studying the $\mathrm{PH}$ effect on the chemical deposited SnS films, using a deposition time of $3 \mathrm{~h}$. It is important to note that the reported methods to obtain orthorhombic SnS by CBD use deposition times of $8,17,24,30$, and up to $40 \mathrm{~h}[20,21,25-27]$ and just a few use times below $6 \mathrm{~h}$ [28-30]. In the work of Higareda et al. [24], they observed a sulfur excess in the chemical solution when the amount of tin precursor was varied in percentages lower than $5 \%$. Thus, to obtain SnS thin films with better crystallinity and stoichiometry, we focused on investigating the effect of the tin precursor increase. Additionally, we varied the deposition time in order to obtain thicker layers. The used procedure allowed us to grow single-phase orthorhombic SnS thin films of $390 \mathrm{~nm}$ in $3.5 \mathrm{~h}$. The structural, morphological, and optical properties of $\mathrm{SnS}$ thin films were studied as a function of deposition time, percentage of $\mathrm{Sn}$ precursor, and thermal treatments. The photoluminescence technique was used to identify recombination mechanisms that could affect the performance of the SnS thin film as an absorber layer in a solar cell.

\section{Materials and Methods}

$\mathrm{SnS}$ thin films were prepared using the chemical bath that contained $0.564 \mathrm{~g}$ of tin chloride $\left(\mathrm{SnCl}_{2} \cdot \mathrm{H}_{2} \mathrm{O}\right)$ as the tin precursor, $1.697 \mathrm{~g}$ of ammonium citrate $\left(\mathrm{C}_{6} \mathrm{H}_{17} \mathrm{~N}_{3} \mathrm{O}_{7}\right)$ as complexing agent, and $0.617 \mathrm{~g}$ of sodium thiosulfate $\left(\mathrm{Na}_{2} \mathrm{~S}_{2} \mathrm{O}_{3} \cdot 5 \mathrm{H}_{2} \mathrm{O}\right)$ as sodium precursor.

Soda-lime glasses used as substrates were cleaned in subsequent ultrasonic baths (liquid soap, deionized water, acetone, and methanol). Afterwards, they were rinsed with deionized water and dried with nitrogen. Initially, the chemical bath showed a dark brown appearance and changed to dark brown with increasing time. The deposition time and tin precursor concentration used in the deposition process is shown in Table 1 . The most homogeneous and hole-free deposited faces of the substrates were selected using a light source behind the sample and varying the viewing angle. The selected face was cleaned with deionized water for further characterization.

Table 1. SnS thin-film samples conditions prepared by CBD and crystallite estimated size.

\begin{tabular}{cccccc}
\hline \multirow{2}{*}{ Samples } & \multicolumn{2}{c}{ Growth Parameters } & \multicolumn{2}{c}{ Crystallographic Direction (111) } \\
\cline { 2 - 6 } & Time (h) & $\mathbf{S n C l}_{\mathbf{2}}$ Concentration (\%) & $\mathbf{2 \theta}\left(^{\circ}\right)$ & $\mathbf{a}\left(^{\circ}\right)$ & $\mathbf{D}(\mathbf{n m})$ \\
\hline S1 & 3.0 & 100 & 31.54 & 0.41 & 72 \\
S2 & 3.5 & 100 & 31.52 & 0.36 & 82 \\
S3 & 3.5 & 150 & 31.54 & 0.36 & 81 \\
\hline
\end{tabular}

Post-growth thermal annealing was performed in all samples to verify the thermal stability. The parameters for the annealing were defined as presented by Ristov et al. [31], heating the samples to $285^{\circ} \mathrm{C}$ for $30 \mathrm{~min}$ in an air atmosphere.

The crystal structure was characterized by grazing incidence X-ray diffraction (XRD, SIEMENS, Munich, Germany). Spectra were obtained using a Siemens D5000 diffractometer 
with an incident angle of 1 degree; the measurement was performed in $2 \theta$ sweeping from 10 to 80 degrees with a scan speed of $0.02^{\circ} / 3 \mathrm{~s}$ using a $\mathrm{Cu} \mathrm{k} \alpha$ tube $(\lambda=1.5406 \AA$ ). Observations of the surface morphology were carried out using a JEOL JSM-7600F scanning electron microscope (SEM, JEOL, Tokio, Japan) with $2 \mathrm{kV}$ of accelerating voltage. The optical transmittance measurements were made using a JASCO 670 spectrophotometer (JASCO, Portland, OR, USA). PL measurements were carried out at $20 \mathrm{~K}$ using a closed cycle He cryostat (SHI-APD Cryogenics Inc., London, UK). The samples were measured in the UV-VIS region using a $442 \mathrm{~nm}$ line of HeCd laser as the excitation source. In this case, the PL signal was detected using HRD-100 Jobin-Yvon double monochromator (HORIBA, Kyoto, Japan) and Ag-Cs-O Hamamatsu photomultiplier (HAMAMATSU, Hamamatsu, Japan). The infrared sample emission was obtained using a $488 \mathrm{~nm}$ Argon ion laser line and recorded by Acton monochromator (Laser physics, West Jordan, UT, USA) and InGaAs detector (HORIBA, Kyoto, Japan).

\section{Results and Discussion}

\subsection{Structural Studies}

Figure 1 shows the XRD pattern of the samples, which agrees with the typically reported structure of the orthorhombic SnS phase (reference COD \#96-152-7226). Here, we could not notice any peak related to the trigonal $\mathrm{SnS}_{2}$ secondary phase (reference COD \# 96-703-8081), except in sample S1, where a low-intensity peak in the (001) direction is observed [10,32]. In the figure, it can be seen that as the deposition time and the concentration of the Sn precursor increased, the peaks corresponding to the orthorhombic SnS phase were further accentuated. These effects, produced by the change of the growth conditions, could be indicating an improvement in the crystalline quality of the sample.

We determined the crystallites size (D) in the principal crystallographic direction (111) using Scherrer's formula:

$$
\mathrm{D}=\frac{\mathrm{K} \cdot \lambda}{\mathrm{a} \cdot \cos \theta}
$$

where $K$ is the form factor, $\lambda$ is the wavelength of the $X$-ray source, $\theta$ is the angle of the Bragg reflection, and $\mathrm{a}$ is the full width at half medium (FWHM) of the diffraction peak in radians. In our case, the form factor used was $\mathrm{K}=0.9$ and $\lambda=1.5418 \AA$ corresponding to the $\mathrm{K} \alpha$ line of copper. The results obtained can be seen in Table 1 . We can observe that as the chemical bath time increased, the crystallite size also increased. While increasing the concentration of the Sn precursor, the crystallite size remained practically constant. This indicates that increasing the Sn precursor concentration during growth improves the quality of the crystalline structure, and the SnS orthorhombic phase formation is promoted. The diffractograms of sample S3 before and after the thermal annealing is shown in Figure 1. It can be noted that after the annealing, the XRD pattern remains almost unchanged, indicating that the main phase of $\mathrm{SnS}$ was not affected. This result agrees with the reported results in previous studies [24].

\subsection{Morphological Studies}

The thin films' morphology was analyzed using scanning electron microscopy. The SEM image of sample S3, before and after the thermal annealing, is shown in Figure 2a,b. We can see elongated structures formed by smaller grains with an average size between $100 \mathrm{~nm}$ and $120 \mathrm{~nm}$, respectively. This morphology has been previously reported for SnS thin films $[33,34]$. The figure shows a certain degree of coalescence between the grains and a compact bulk.

It should be noted that the annealing of the samples slightly increased the coalescence of the grains but did not affect the rest of the morphological characteristics of the samples. The thicknesses obtained from cross-sectional SEM images were $373 \mathrm{~nm}$ and $390 \mathrm{~nm}$ for S2 and S3 (see Figure 2c,d). For sample S1, the thickness value could not be obtained due to the low thickness of the sample, which was identified visually. 


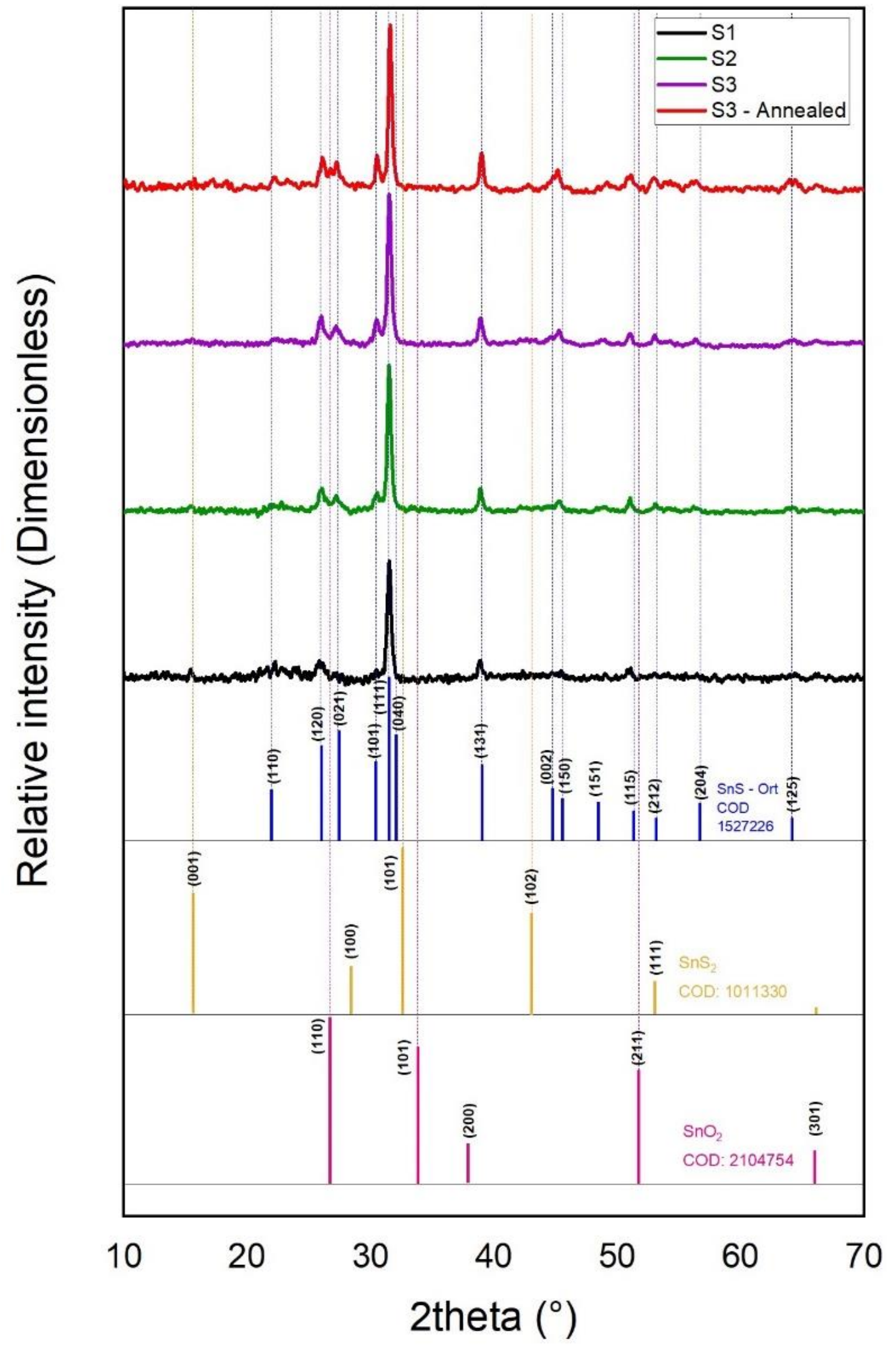

Figure 1. XRD pattern of samples $\mathrm{S} 1, \mathrm{~S} 2, \mathrm{~S} 3$ as deposited and $\mathrm{S} 3$ after the thermal annealing. 


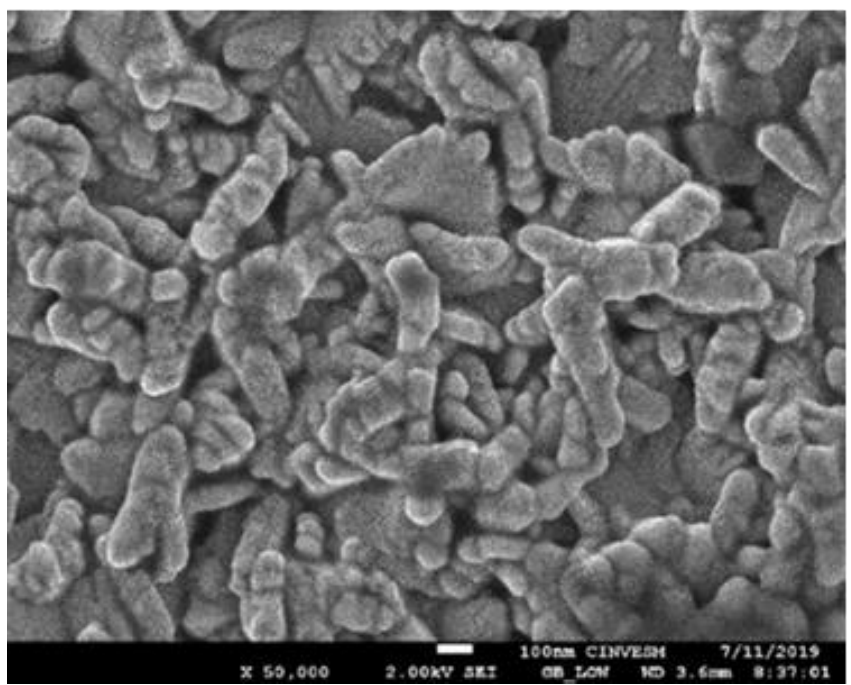

(a)

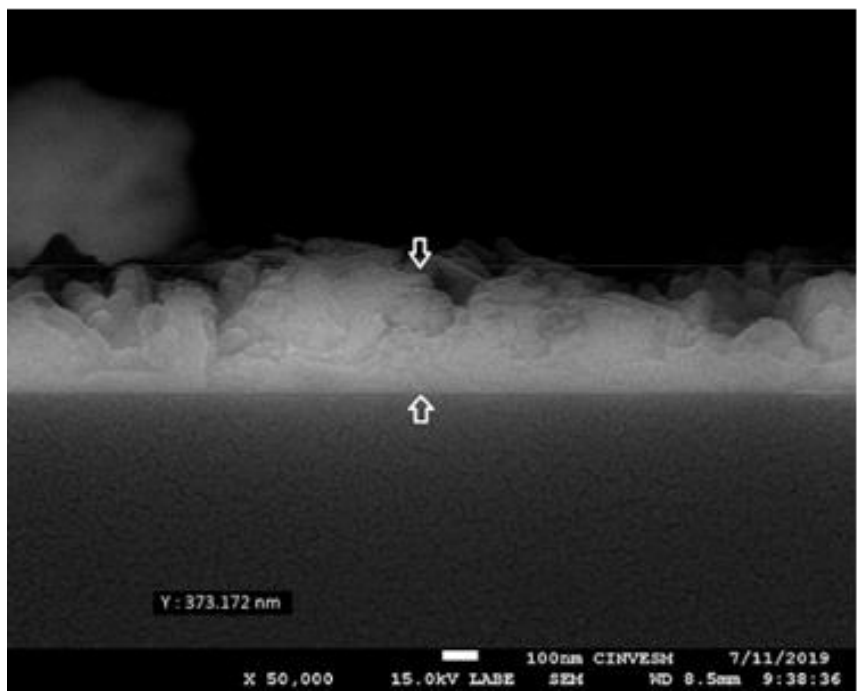

(c)

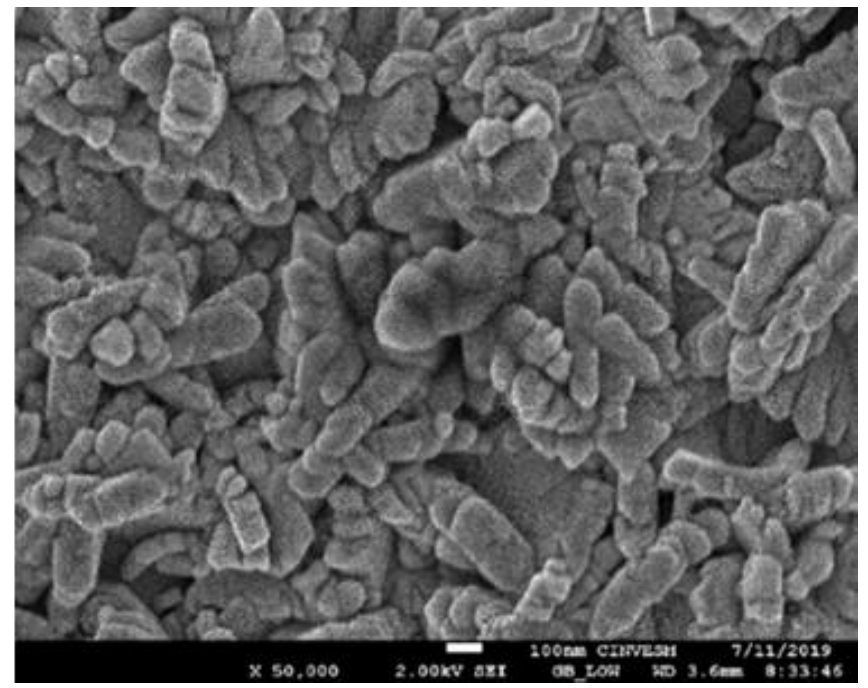

(b)

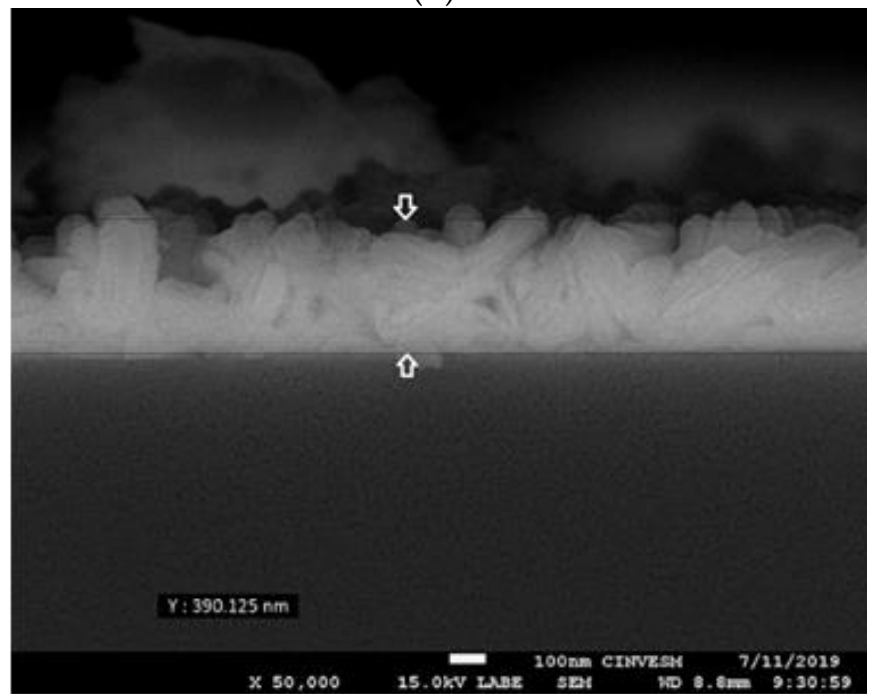

(d)

Figure 2. SEM micrograph for sample S3 (a) with and (b) without port-annealing and cross-section of samples (c) S2 and (d) S3.

\subsection{Optical Studies}

To obtain the bandgap values, the optical transmittance for the as-deposited and annealed SnS films, samples S2 and S3, was recorded in the 400-1100 nm wavelength. Figure 3a shows the optical transmittance for sample $\mathrm{S} 3$ and the shift in the absorption edge after the annealing. Figure $3 b, c$ shows the Tauc plot for sample S3 to determine the optical bandgap, using the expression:

$$
(\alpha \mathrm{hv})^{2}=\mathrm{A}\left(\mathrm{hv}-\mathrm{E}_{\mathrm{g}}\right)
$$

where $\propto$ is the absorption coefficient, $\mathrm{E}_{\mathrm{g}}$ is the bandgap energy, $\mathrm{h} v$ is the photon energy, and $\mathrm{A}$ is a constant. A linear region in the Tauc plot indicates direct gap material, with an estimated energy gap of $1.56 \mathrm{eV}$ and $1.53 \mathrm{eV}$ for sample $\mathrm{S} 3$ before and after annealing, respectively. The same procedure was applied to sample S2. 

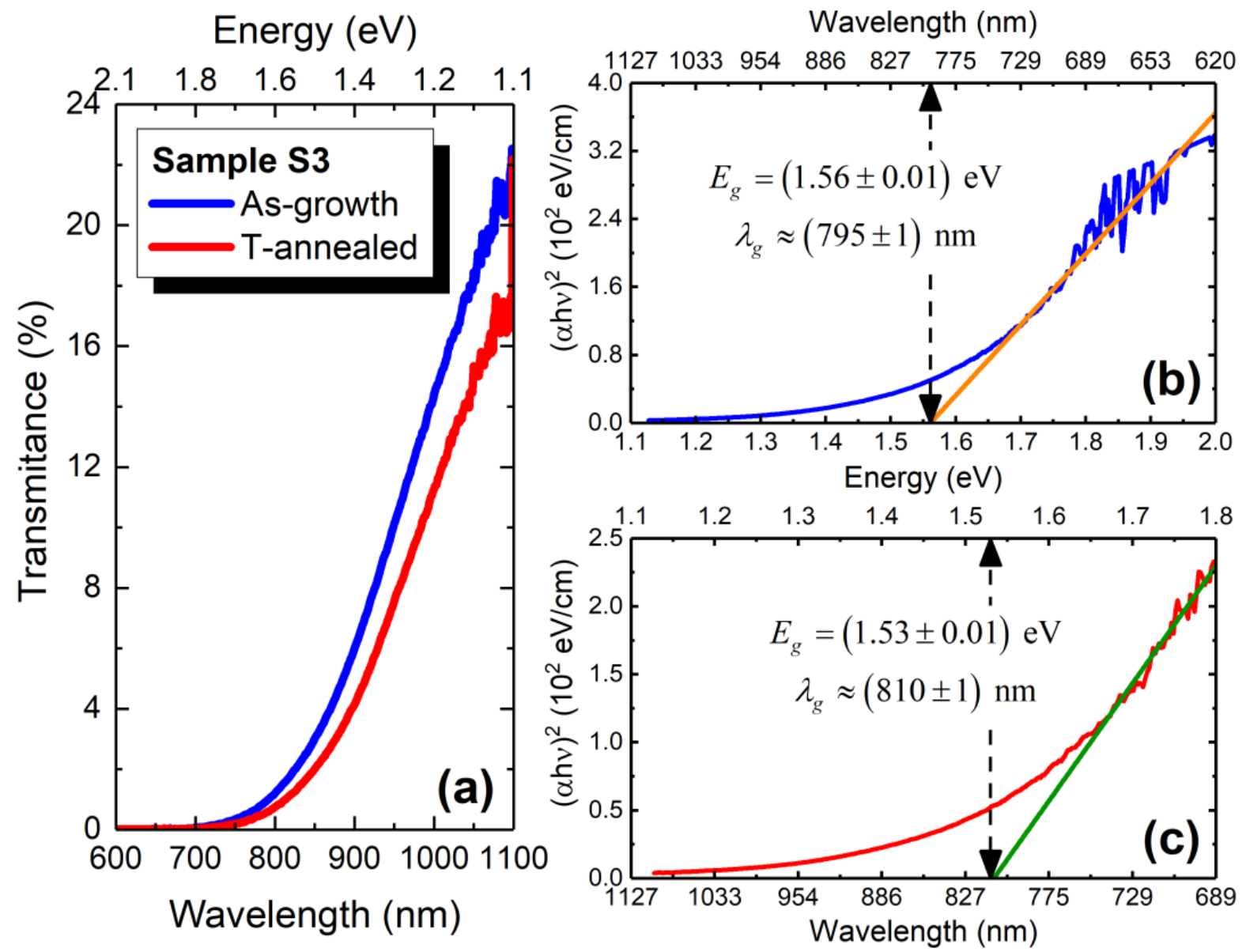

Figure 3. (a) Transmittance spectrum of sample S3 before and after the thermal annealing. (b) Fitted Tauc plot of sample S3 before and (c) after the thermal annealing.

Table 2 summarizes the bandgap energies obtained for samples S2 and S3. In the case of sample S1, a conclusive result in the transmittance measurement could not be obtained due to the low sample thickness. Because of the lack of bandgap and thickness data for sample S1, we continue the subsequent optical studies only with S2 and S3.

Table 2. Optical bandgap of SnS thin films before and after air annealing.

\begin{tabular}{ccc}
\hline \multirow{2}{*}{ Sample } & \multicolumn{2}{c}{ Eg (eV) } \\
\cline { 2 - 3 } & As-Growth & T-Annealed \\
\cline { 2 - 3 } S2 & $1.41 \pm 0.01$ & $1.42 \pm 0.01$ \\
S3 & $1.56 \pm 0.01$ & $1.53 \pm 0.01$ \\
\hline
\end{tabular}

The bandgap energy obtained for sample S2 $(1.41 \mathrm{eV})$ agrees with the values reported in the literature for orthorhombic SnS deposits [2]. However, for sample S3, the bandgap energy is slightly higher. This can be explained considering that sample S3 is richer in $\mathrm{Sn}$, which favors the formation of $\mathrm{SnO}_{2}$ due to the greater availability of $\mathrm{Sn}$. Therefore, the optical bandgap of sample S3 increases $(1.56 \mathrm{eV})$. Other authors have reported similar behavior after air annealing of SnS thin films [35]. This result is supported by the PL measurements presented in the Section 4 in Figure 4a. Table 2 also shows that heat treatment in both samples S2 and S3 does not modify its bandgap energy. They are similar if we consider the error values. This indicates that both samples are thermally stable, maintaining their optical properties. 


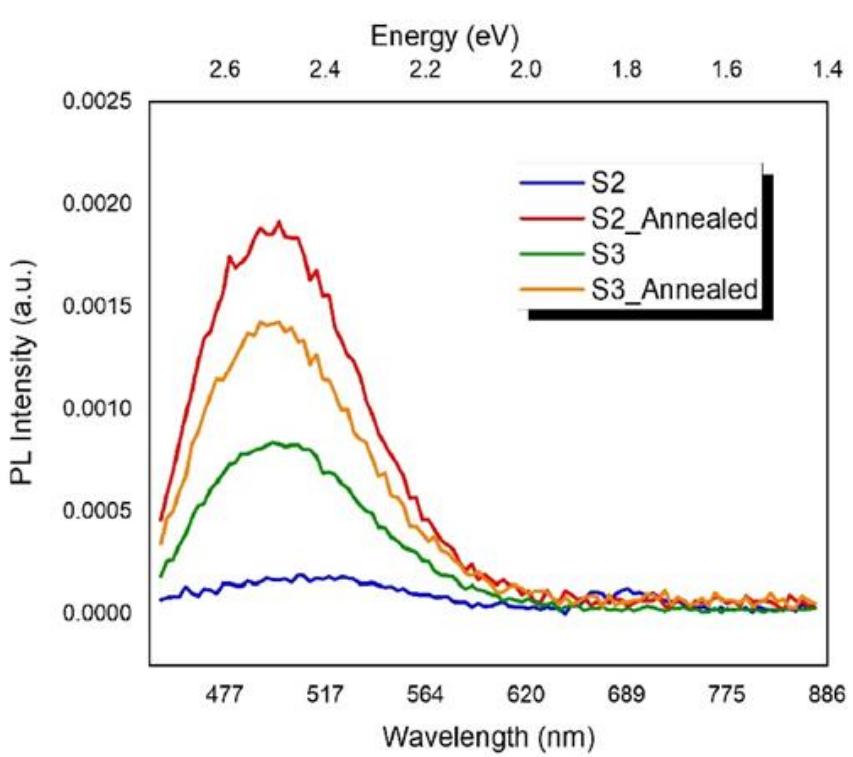

(a)

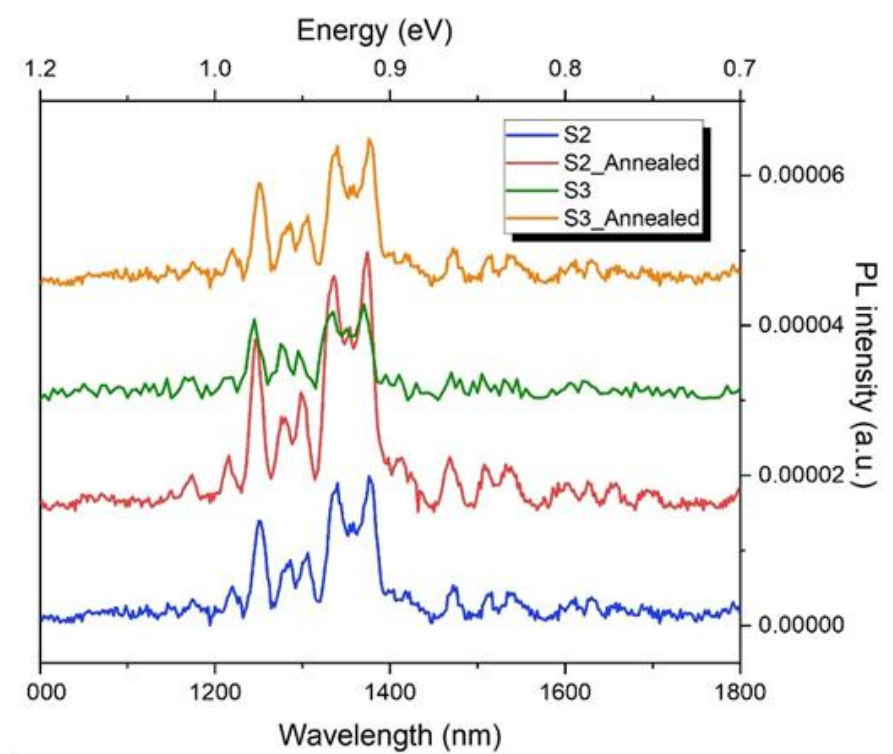

(b)

Figure 4. PL spectra for as deposited and annealed SnS films recorded at $20 \mathrm{~K}$ for (a) visible and (b) infrared range.

Low-temperature PL spectroscopy was used to investigate the radiative recombination processes of SnS films. Most of the PL studies of SnS films reported in the literature are carried out in the visible range of the spectrum. However, there are very few reports on photoluminescence in the infrared region. Figure 4a shows PL spectra of S2 and S3 before and after annealing in the UV-Vis region with photon excitation at $442 \mathrm{~nm}$. A broad and asymmetric band was observed around $2.50 \mathrm{eV}$ for both samples. We associated this band with the $\mathrm{SnO}_{2}$ presence [31,36,37]. The peak corresponding to the Sn-rich sample, S3, has a higher PL intensity than S2 due to the greater formation of the oxide compound, as explained previously. After annealing, performed in an air atmosphere, the transformation of $\mathrm{SnS}$ into $\mathrm{SnO}_{2}$ is promoted by following the reaction [34].

$$
2 \mathrm{SnS}+\mathrm{O}_{2} \rightarrow \mathrm{SnO}_{2}+\mathrm{SnS}_{2}
$$

The formation of $\mathrm{SnO}_{2}$ can be explained by the oxidation of $\mathrm{Sn}$ (II) to $\mathrm{Sn}$ (IV).

We performed a PL study between 1000-1800 $\mathrm{nm}$ to observe deep-level states in $\mathrm{SnS}$ samples. Figure $4 \mathrm{~b}$ displays PL spectra in the infrared region for samples excited at $488 \mathrm{~nm}$. We can see a multi-peak emission between $0.90 \mathrm{eV}$ and $0.99 \mathrm{eV}$. The bands' intensity increased after annealing, suggesting that these emissions may be due to deep oxygen-related levels. This behavior was observed by Sajeesh et al. [33], whose reported deep-level transitions were attributed to the presence of oxygen. According to the results presented, sample S3, compared to samples S1 and S2, would be a better candidate for use in solar cells due to its better crystallinity of orthorhombic single phase without the need for post-deposition heat treatment. In addition, as mentioned above, deposition times from $6 \mathrm{~h}$ to $30 \mathrm{~h}$ have been reported in the literature. We use a method that allows us to grow SnS with thickness values close to that used in the recorded cell in shorter times. This has allowed us to work on bilayers for future applications in photovoltaic structures. Further studies are currently underway to determine the nature of the emissions found in the infrared range to optimize the film's properties for use in photovoltaic structures.

\section{Conclusions}

SnS thin films with a thickness of $390 \mathrm{~nm}$ are deposited in $3.5 \mathrm{~h}$ at room temperature. The XRD analysis reveals orthorhombic structures with a low presence of the $\mathrm{SnS}_{2}$ phase. The study showed that as the deposition time and the concentration of the Sn precursor in 
the bath increased, the peaks corresponding to the orthorhombic SnS phase were further accentuated, indicating an improvement in the crystalline quality of the sample. However, greater availability of $\mathrm{Sn}$ leads to a more significant formation of $\mathrm{SnO}_{2}$ and a slightly higher optical bandgap. SEM images show that deposited films are homogenous, formed by smaller grains with an average size between $100 \mathrm{~nm}$ and $120 \mathrm{~nm}$. PL characterization confirmed the presence of $\mathrm{SnO}_{2}$ through a band located around $2.4 \mathrm{eV}$, whose intensity increases with thermal treatment in air. PL emission bands were found in the infrared region, probably due to deep levels related to oxygen.

Author Contributions: Conceptualization, C.O.-O., I.R. and A.A.; validation, I.R., A.A. and R.M.-F.; formal analysis, C.O.-O. and A.A.; investigation, C.O.-O., R.M.-F. and P.R.-F.; writing-original draft preparation, C.O.-O. and A.A.; writing-review and editing, I.R. and J.M.-A. All authors have read and agreed to the published version of the manuscript.

Funding: This research was funded by CONACYT-SENER under contract 254667.

Institutional Review Board Statement: Not applicable.

Informed Consent Statement: Not applicable.

Data Availability Statement: Not applicable.

Acknowledgments: Carlos Ocampo-Ortega acknowledge the financial support by the CONACYT Postgraduate Scholarship. The authors thank LANNBIO CINVESTAV-Mérida for SEM measurements.

Conflicts of Interest: The authors declare no conflict of interest. The funders had no role in the design of the study; in the collection, analyses, or interpretation of data; in the writing of the manuscript; or in the decision to publish the results.

\section{References}

1. Sohila, S.; Rajalakshmi, M.; Ghosh, C.; Arora, A.; Kand, M. Optical and Raman scattering studies on SnS nanoparticles. J. Alloys Compd. 2011, 509, 5843-5847. [CrossRef]

2. Jacob, A.; Maykel, C.; Osvaldo, V. SnS-based thin film solar cells: Perspectives over the last 25 years. J. Mater. Sci. Mater. Electron. 2015, 26, 4541-4556.

3. Araújo, G.L.; Martí, A. Absolute limiting efficiencies for photovoltaic energy conversion. Solar Energy Mater. Sol. Cells 1994, 33, 213-240. [CrossRef]

4. Sinsermsuksakul, P.; Sun, L.; Lee, S.W.; Park, H.H.; Kim, S.B.; Yang, C.; Gordon, R.G. Overcoming Efficiency Limitations of SnS-Based Solar Cells. Adv. Energy Mater. 2014, 4, 1400496. [CrossRef]

5. Lee, A.B.; Aron, W. Phase Stability of the Earth-Abundant Tin Sulfides SnS, SnS 2 , and Sn2S 3 . J. Phys. Chem. C 2012, 116, $24262-24267$.

6. Sreedevi, G.; Vasudeva, M.R.; Babu, P.; Chinho, P.; Chan-Wook, J.; Tulasi, R.K. Studies on chemical bath deposited SnS 2 films for Cd-free thin film solar cells. Ceram. Int. 2017, 43, 3713-3719.

7. $\quad$ El-Nahass, M.M.; Zeyada, H.M.; Aziz, M.S.; El-Ghamaz, N.A. Optical properties of thermally evaporated SnS thin films. Opt. Mater 2002, 20, 159-170. [CrossRef]

8. Ikuno, T.; Suzuki, R.; Kitazumi, K.; Takahashi, N.; Kato, N.; Higuchi, K. SnS thin film solar cells with Zn1-xMgxO buffer layers. Appl. Phys. Lett. 2013, 102, 193901. [CrossRef]

9. Tanusevski, A.; Poelman, D. Optical and photoconductive properties of SnS thin films prepared by electron beam evaporation. Sol. Energy Mater. Sol. Cells 2003, 80, 297-303. [CrossRef]

10. Sinsermsuksakul, P.; Hartman, K.; Kim, S.B.; Heo, J. Enhancing the efficiency of SnS solar cells via band-offset engineering with a zinc oxysulfide buffer layer. Appl. Phys. Lett. 2013, 102, 053901. [CrossRef]

11. Ghosh, B.; Chowdhury, S.; Banerjee, P.; Das, S. Fabrication of CdS/SnS heterostructured device using successive ionic layer adsorption and reaction deposited SnS. Thin Solid Film. 2011, 519, 3368-3372. [CrossRef]

12. Ichimura, M.; Takeuchi, K.; Ono, Y.; Arai, E. Electrochemical deposition of SnS thin films. Thin Solid Film. 2000, 361, 98-101. [CrossRef]

13. Kamel, M.M.; Ibrahim, M.M. Electrochemical deposition and characterization of SnS thin films. J. Solid State Electrochem. 2011, 15, 683-688. [CrossRef]

14. Ninan, G.G.; Kartha, C.S.; Vijayakumar, K.P. Spray pyrolysed SnS thin films in $\mathrm{n}$ and $\mathrm{p}$ type: Optimization of deposition process and characterization of samples. J. Anal. Appl. Pyrolysis 2016, 120, 121-125. [CrossRef]

15. Thangaraju, B.; Kaliannan, P. Spray pyrolytic deposition and characterization of SnS and SnS 2 thin films. J. Phys. D Appl. Phys. 2000, 33, 1054-1059. [CrossRef] 
16. Avellaneda, D.; Nair, M.T.; Nair, P.K. Polymorphic tin sulfide thin films of zinc blende and orthorhombic structures by chemical deposition. J. Electrochem. Soc. 2008, 155, D517. [CrossRef]

17. Nair, M.T.; Nair, P.K. Simplified chemical deposition technique for good quality SnS thin films. Semicond. Sci. Technol. 1991, 6, 132. [CrossRef]

18. Giampaolo, T.G.; Mary, F.M.; Molloy, K.C.; Price, L.S.; Parkin, I.P.; Hardy, A.M.; Field, M.N. Deposition of tin sulfide films from tin(IV) thiolate precursors. J. Mater. Chem. 2001, 11, 464-468.

19. Chao, G.; Honglie, S.; Lei, S. Preparation and properties of zinc blende and orthorhombic SnS films by chemical bath deposition. Appl. Surf. Sci. 2011, 257, 6750-6755.

20. Avellaneda, D.; Delgado, G.; Nair, M.T.; Nair, P.K. Structural and chemical transformations in SnS thin films used in chemically deposited photovoltaic cells. Thin Solid Films 2007, 515, 5771-5776. [CrossRef]

21. Güneri, E.; Ulutas, C.; Gode, F.; Gumus, C. Properties of p-type SnS thin films prepared by chemical bath deposition. Chalcogenide Lett. 2011, 7, 685-694.

22. Garcia- Angelmo, A.R.; Romano-Trujillo, R.; Campos-Alvarez, J.; Daza, O.G.; Nair, M.T.; Nair, P.K. Thin film solar cell of SnS absorber with cubic crystalline structure. Phys. Status Solidi A 2015, 212, 2332-2340. [CrossRef]

23. Ammar, I.; Gassoumi, A.; Akkari, A. Deposition of SnS thin films by chemical bath deposition method: Effect of surfactants. Eur. Phys. J. Plus 2019, 134, 505. [CrossRef]

24. Higareda-Sánchez, A.; Mis-Fernández, R.; Rimmaudo, I.; Camacho-Espinosa, E.; Peña, J.L. Evaluation of pH and deposition mechanisms effect on tin sulfide thin films deposited by chemical bath deposition. Superlattices Microstruct. 2021, 151, 106831 [CrossRef]

25. Treviño-Yarce, L.; Rosendo, E.; Romano-Trujillo, R.; Morales, C.; Díaz-Becerril, T.; Silva, R.; Galeazzi, R.; Coyopol, A.; García, G. Morphological changes of SnS thin films deposited on stainless-steel substrates at low temperatures. Eur. J. Eng. Res. Sci. 2019, 4, 1-4. [CrossRef]

26. Avellaneda, D.; Sánchez-Orozco, I.; Aguilar Martínez, J.A.; Shaji, S.; Krishnan, B. Thin films of tin sulfides: Structure, composition and optoelectronic properties. Mater. Res. Express 2018, 6, 016409. [CrossRef]

27. Nair, P.K.; Garcia-Angelmo, A.R.; Nair, M.T.S. Cubic and orthorhombic SnS thin-film absorbers for tin sulfide solar cells. Phys. Status Solidi 2016, 213, 170-177. [CrossRef]

28. Ben Mbarek, M.; Reghima, M.; Yacoubi, N.; Barradas, N.; Alves, E.; Bundaleski, N.; Teodoro, O.; Kunst, M.; Schwarz, R. Microwave transient reflection in annealed SnS thin films. Mater. Sci. Semicond. Process. 2021, 121, 105302. [CrossRef]

29. Marquez, I.G.; Romano-Trujillo, R.; Gracia-Jimenez, J.M.; Galeazzi, R.; Silva-González, N.R.; García, G.; Coyopol, A.; NietoCaballero, F.G.; Rosendo, E.; Morales, C. Cubic, orthorhombic and amorphous SnS thin films on flexible plastic substrates by CBD. J. Mater. Sci. Mater. Electron. 2021, 32, 15898-15906. [CrossRef]

30. Cao, M.; Zhang, X.; Ren, J.; Sun, Y.; Cui, Y.; Zhang, J.; Ling, J.; Huang, J.; Shen, Y.; Wang, L. Chemical bath deposition of SnS:Cu/ZnS for solar hydrogen production and solar cells. J. Alloys Compd. 2021, 863, 158727. [CrossRef]

31. Ristov, M.; Sinadinovski, G.; Grozdanov, I.; Mitreski, M. Chemical deposition of thin (ii) sulfide thin films. Thin Solid Films 1989, 173, 53-58. [CrossRef]

32. Srinivasa, R.T.; Hemanth, K.B.; Santhhosh, M.C. Effect of annealing on the optical properties and photoconductivity of SnS thin film. In Proceedings of the DAE Solid State Physics Symposium, Bhubaneswar, India, 26-30 December 2016.

33. Sajeesh, T.H.; Poornima, N.; Sudha Kartha, C.; Vijayakumar, K.P. Unveiling the defect levels in SnS thin films for photovoltaic applications using photoluminescence technique. Phys. Status Solidi A 2010, 207, 1934-1939. [CrossRef]

34. Jeong, J.; Choi, S.P.; Chang, C.I.; Shin, D.C.; Park, J.S.; Lee, B.T.; Park, Y.J.; Song, H.J. Photoluminescence properties of SnO 2 thin films grown by thermal CVD. Sol. State Commun. 2003, 127, 595-597. [CrossRef]

35. Mathews, N.R.; Colín García, C.; Torres, I.Z. Effect of annealing on structural, optical and electrical properties of pulse electrodeposited tin sulfide films. Mater. Sci. Semicond. Process. 2013, 16, 29-37. [CrossRef]

36. Chang, S.S.; Park, D.K. Novel Sn powder preparation by spark processing and luminescence properties. Mater. Sci. Eng. 2002, 95, 55-60. [CrossRef]

37. Luo, S.; Fan, J.; Liu, W.; Zhang, M.; Song, Z.; Lin, C.; Chu, P.K. Synthesis and low-temperature photoluminescence properties of $\mathrm{SnO}_{2}$ nanowires and nanobelts. Nanotechnology 2006, 17, 1695-1699. [CrossRef] 